INDONESIAN JOURNAL OF

Clinical Pathology and Medical Laboratory

Majalah Patologi Klinik Indonesia dan Laboratorium Medik

\begin{tabular}{|c|c|c|c|c|c|}
\hline $\begin{array}{c}\text { IJCP \& ML } \\
\begin{array}{c}\text { (Maj. Pat. Klin. } \\
\text { Indonesia \& Lab. Med.) }\end{array}\end{array}$ & Vol. 17 & No. 3 & Hal. 127-177 & $\begin{array}{c}\text { Surabaya } \\
\text { Juli 2011 }\end{array}$ & $\begin{array}{c}\text { ISSN } \\
0854-4263\end{array}$ \\
\hline
\end{tabular}

Diterbitkan oleh Perhimpunan Dokter Spesialis Patologi Klinik Indonesia

Published by Indonesian Association of Clinical Pathologists

Terakreditasi No: 43/DIKTI/Kep/2008, Tanggal 8 Juli 2008 


\section{INDONESIAN JOURNAL OF \\ CLINICAL PATHOLOGY AND MEDICAL LABORATORY \\ Majalah Patologi Klinik Indonesia dan Laboratorium Medik}

\section{DAFTAR ISI}

\section{PENELITIAN}

Creatine Kinase Myocardial Band, Myeloperoxidase, Matrix Metalloproteinase- 9 dan Troponin T Pada IMA

(The Creatine Kinase Myocardial Band, Myeloperoxidase, Matrix Metalloproteinase-9 Activities and Troponin $T$ in Myocardial Infarction)

IA Hutagalung, I Patellongi, R Pakasi, M Arif, AA Mappahya, Hardjoeno

D-Dimer Penderita Sindrom Koroner Akut dan Stenosis

(D-Dimer in Acute Coronary Syndrome and Stenosis)

Birhasani, Lisyani BS, Ria T

Uji Hematologi Pasien Terduga Demam Berdarah Dengue Indikasi Rawat Inap

(Hematology Test of Dengue Hemorrhagic Fever on Suspected Patients Indicated for Hospitalization) Juranah, Darwati Muhadi, Mansyur Arif, Burhanuddin Bahar .

Imunokimiawi PGE2 Usus Ileum yang Kekurangan Energi Protein

(Immunohistochemistry of PGE2 Ileum Intestine Protein Energy Deficiency)

R. Heru Prasetyo

Gamma-glutamyltransferase dan Apolipoprotein B dengan Sindroma Metabolik

(Gamma-glutamyltransferase and Apolipoprotein B with the Metabolic Syndrome)

Tahono, M.I. Diah Pramudianti.

146-150

Umbi Ubi Jalar Ungu Bali (Ipomoea batatas) di Transaminase Serum, Malondialdehide Hepar dan Alkohol Kronis

(Balinese Purple Sweet Potato (Ipomoea batatas L) on SGOT, SGPT, MDA level and Chronic Alcohol) I Wayan Putu Sutirta-Yasa, I Made Jawi, Ida Bagus Ngurah, Anak Agung Ngurah Subawa.

Leukosit Infeksi Bakteri Sistemik

(Leucocyte in Systemic Bacterial Infections)

Meita Hendrianingtyas, MI. Tjahjati DM

Meningitis Tuberculosis

(Meningitis Tuberculosis)

Silvia Rachmayati, Ida Parwati, A Rizal, D Oktavia

Platelet Aggregation In Acute Coronary Syndrome

(Aggregasi Trombosit di Sindroma Koroner Akut)

Sulianty, Adi K Aman..

TELAAH PUSTAKA

Pemetaan Epitop dan Aplikasi Klinisnya

(Epitope Mapping and It's Clinical Aplication)

Jusak Nugraha.

LAPORAN KASUS

Infeksi Virus Rabies di Anak-anak

(Rabies Virus Infection in Children)

A.A.N. Subawa, DGD. Dharma Santhi, A.A Raka Sudewi, IWP. Sutirta Yasa 


\title{
INFEKSI VIRUS RABIES DI ANAK-ANAK
}

\author{
(Rabies Virus Infection in Children)
}

A.A.N. Subawa ${ }^{1}$, DGD. Dharma Santhi ${ }^{1}$, A.A Raka Sudewi ${ }^{2}$, IWP. Sutirta Yasa ${ }^{1}$

\begin{abstract}
Rabies has been known in ancient Egypt and China since the fifth century. The disease is caused by the Rhabdovirus of the genus Lyssavirus spread from animals or bats to humans by saliva. A five-year-old kid was admitted to Sanglah General Hospital on February 19. 2010 with fever complaints, before admitted to the hospital, since the morning he always stuck out his tongue, bit his lips, drinking a little of water and hard to swallow. From the anamnesis, it is known that the patient has a history of bitten by a dog on February 4. 2010 at the lower eyelid and had received wound treatment and VAR, after a while having the treatment the patient eventually died on February 21. 2010. According to the post-mortem sample of the LCS it is showed a positive PCR result of rabies virus infection.
\end{abstract}

Key words: Rabies virus infection, children

\begin{abstract}
ABSTRAK
Rabies telah dikenal sejak zaman Mesir dan Cina kuno pada abad kelima. Penyakit ini disebabkan oleh Rhabdovirus genus Lyssavirus, yang disebarkan melalui air liur binatang biasanya kelelawar, kepada manusia. Seorang anak laki-laki berusia lima tahun dibawa ke Rumah Sakit Umum Sanglah pada tanggal 19 Februari 2010 dengan keluhan demam sejak pagi hari. Sebelum masuk rumah sakit, pasien selalu menjulurkan lidah dan menggigit bibirnya, minum air hanya sedikit dan susah menelan air. Dari anamnesis melalui keluarga diketahui bahwa pasien memiliki riwayat digigit anjing pada tanggal 4 Februari 2010 di kelopak mata bawah dan sudah mendapatkan perawatan luka dan VAR dosis pertama. Namun, setelah tiga hari mendapatkan perawatan, akhirnya pasien meninggal pada tanggal 21 Februari 2010. Hasil PCR pascakematian (post mortem) dari contoh LCS menunjukkan hasil positif terinfeksi virus rabies.
\end{abstract}

Kata kunci: Infeksi virus rabies, anak

\section{PENDAhuluAN}

Rabies merupakan salah satu penyakit infeksi di manusia yang paling lama dikenal. Istilah rabies sudah dikenal sejak zaman Babilonia sekitar abad ke-23 SM, Democritus menulis secara jelas tentang hewan yang menderita rabies pada tahun 500 SM. Rabies adalah penyakit hewan yang disebabkan oleh Rhabdovirus genus Lyssavirus, bersifat akut, menyerang susunan saraf pusat, serta bersifat zoonosis artinya penyakit tersebut dapat menular dari hewan ke manusia. Rabies menyebabkan kematian manusia dengan rerata kasus kematian/CFR (Case Fatality Rate) $100 \% .^{1,2}$ Di Indonesia rabies pertama kali dilaporkan di kerbau oleh Esser (1884), kemudian oleh Penning di anjing (1889) dan oleh De Haan di manusia (1894). ${ }^{3}$

Selama puluhan tahun Bali menjadi salah satu provinsi di Indonesia yang selama ini dinyatakan bebas Rabies. Pada 28 November 2008 untuk pertama kalinya kasus Rabies ditemukan di Bukit PeninsulaUngasan, Kecamatan Kuta Selatan, Kabupaten Badung dan berkembang sampai ke kabupaten lainnya di Propinsi Bali. Propinsi Bali dinyatakan berstatus wabah rabies yang tertuang dalam Peraturan Menteri
Pertanian Nomor 1637/2008, dan ditandatangani Menteri Pertanian Anton Apriyantono pada 1 Desember 2008. ${ }^{3-5}$ Sampai bulan Desember 2010 diketahui sebanyak 45.700 warga Bali terlibat kasus/ mengalami gigitan anjing, dengan kasus kematian sebanyak 113 orang.

Berikut dilaporkan kasus infeksi virus rabies di seorang anak berumur 5 (lima) tahun yang tergigit anjing serta telah mendapatkan Vaksin Anti Rabies (VAR) tetapi pada akhirnya ia meninggal.

\section{KASUS YANG DIBAHAS}

Seorang anak laki-laki berusia lima tahun diantar keluarganya ke Rumah Sakit Sanglah pada tanggal 19 Februari 2010 dengan keluhan panas sejak pagi hari. Sebelum masuk rumah sakit, pasien selalu menjulurkan lidah dan menggigit bibirnya, minum air hanya sedikit dan susah menelan air. Berdasarkan anamnesis keluarga diketahui bahwa pasien memiliki riwayat digigit anjing pada tanggal 4 Februari 2010 di kelopak mata bawah dan sudah mendapatkan perawatan luka dan vaksin anti rabies (VAR) dosis pertama. Anjing yang menggigit 
tidak diketahui pemiliknya dan langsung dibunuh setelah menggigit. Gejala khas infeksi rabies yang ditemukan pada pemeriksaan fisik adalah takut udara (airphobia), takut cahaya (photophobia), serta takut air (hydrophobia). Dosis VAR kedua diperoleh seminggu kemudian yaitu pada tanggal 11 Februari 2010. Hasil periksaan PCR sebelum meninggal pada hari kedua dirawat, dari sampel air mata dan air liur (saliva) menunjukkan hasil negatif.

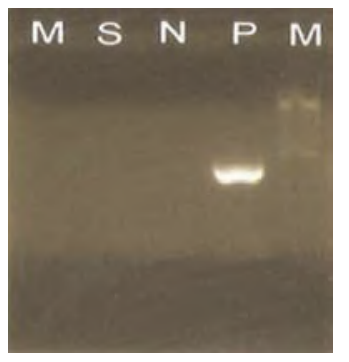

Gambar 1. Pemeriksaan PCR sebelum meninggal Ket. $\mathrm{Mt}=$ mata, $\mathrm{S}=$ saliva, $\mathrm{N}=$ kontrol negatif, $\mathrm{P}=$ kontrol positif, $\mathrm{M}=$ marker

Pengobatan yang diperoleh pasien selama perawatan dapat dibaca di Tabel 1 di bawah ini.

Tabel 1. Pengobatan yang diperoleh selama perawatan

\begin{tabular}{cll}
\hline No. & Pengobatan & Dosis \\
\hline 1. & IVFD 5\% + Diazepam 20 mg & 12 tetes/menit \\
2. & Suntikan (injeksi) Ceftriaxone & $2 \times 1 \mathrm{gram}$ \\
3. & Paracetamol & $3 \times 250 \mathrm{mg}$ \\
4. & Ranitidine & $2 \times 1 / 2 \mathrm{ampul}$ \\
\hline
\end{tabular}

Pasien meninggal pada tangal 21 Februari 2010, setelah tiga hari mendapat perawatan. Pengambilan LCS sampel pascameninggal menunjukkan hasil PCR positif rabies.

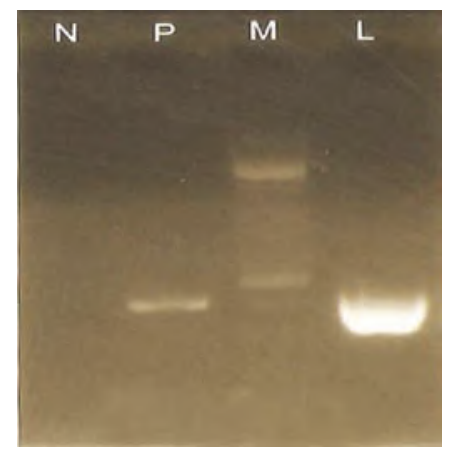

Gambar 2. Pemeriksaan PCR pascameninggal Ket. $\mathrm{N}=$ kontrol negatif, $\mathrm{P}=$ kontrol positif, $\mathrm{M}=$ marker, $\mathrm{L}=\mathrm{LCS}$

\section{PEMBAHASAN}

Cara menular virus Rabies dapat melalui gigitan dan non gigitan (gas berkuman/aerogen, pencangkokan/transplantasi, sentuhan dengan bahan mengandung virus rabies di kulit atau selaput lendir/mukosa yang lecet). ${ }^{6}$ Luka gigitan biasanya merupakan tempat masuk virus melalui air liur, karena virus tidak bisa masuk melalui kulit utuh. Setelah virus rabies masuk melalui luka gigitan, maka selama dua (2) minggu virus tetap tinggal di tempat masuk dan sekitarnya, kemudian bergerak mencapai ujung serabut saraf paling belakang (posterior) tanpa menunjukkan perubahan fungsinya. Bagian otak yang terserang adalah sumsum sambungan (medulla oblongata) dan Annon's horn. Sesampainya di otak, virus kemudian memperbanyak diri dan menyebar luas ke dalam semua bagian satuan sel saraf, terutama sel sistem pinggir (limbik), hipotalamus dan batang otak. Setelah memperbanyak diri dalam sel saraf pusat, virus kemudian ke arah perifer dalam serabut saraf pembawa rangsang (eferen) dan pada saraf volunter maupun saraf otonom. Dengan demikian virus ini menyerang hampir setiap organ dan jaringan di dalam tubuh dan berkembang biak dalam jaringan seperti kelenjar ludah, ginjal dan sebagainya. 1,4,7

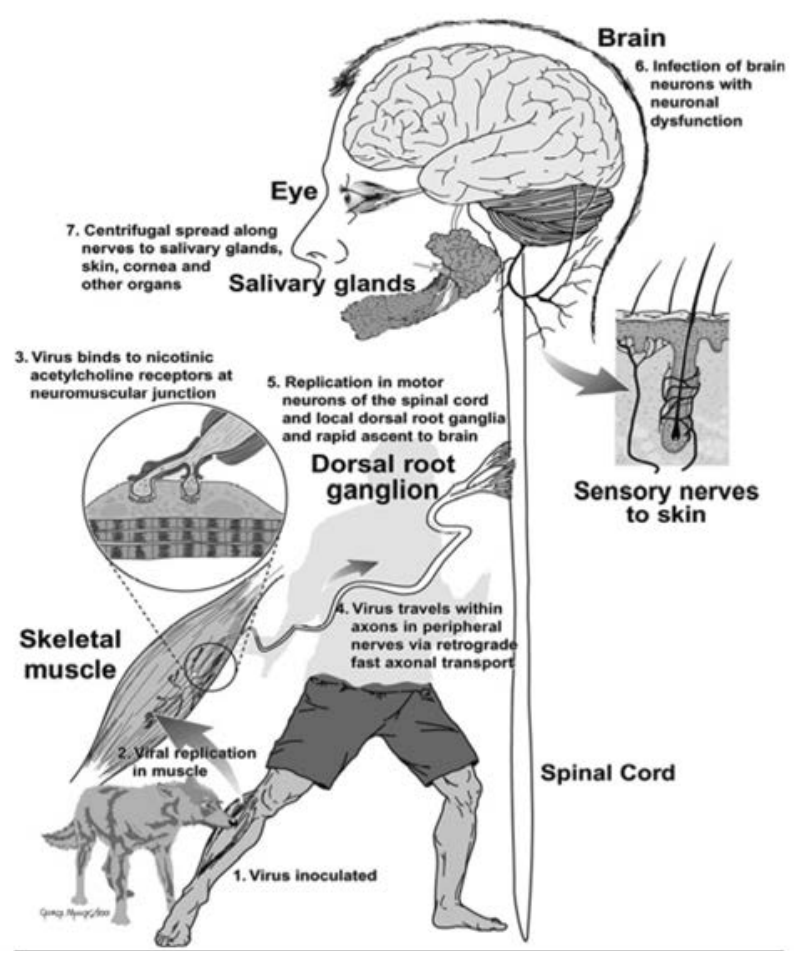

Gambar 3. Bagan patogenesis infeksi virus rabies ${ }^{15}$

Masa inkubasi di manusia beragam, yang khas adalah 1-2 bulan, tetapi dapat sampai 1 (satu) minggu atau selama beberapa tahun (mungkin 6 tahun atau lebih). Biasanya lebih cepat di anak-anak daripada orang dewasa. Kasus rabies manusia dengan masa waktu inkubasi panjang (2 sampai 7 tahun) telah pernah dilaporkan, tetapi jarang terjadi. Masa inkubasi virus rabies bergantung pada umur pasien, latar belakang genetik, status imun, galur virus yang 
terlibat, jumlah virus masuk, dan jarak yang harus ditempuh virus dari titik pintu masuk sampai ke susunan saraf pusat. Gigitan di kaki masa inkubasi kira-kira 60 hari, sedangkan gigitan di tangan masa inkubasi 40 hari, gigitan di kepala masa inkubasi kira-kira 30 hari. ${ }^{1,4,8}$ Di kasus yang dilaporkan, pasien berusia 5 (lima) tahun dan bagian tubuh yang tergigit adalah kelopak mata bawah, sehingga jumlah virus yang masuk dan jarak yang harus ditempuh virus dari titik pintu masuk sampai ke susunan saraf pusat lebih pendek. Dengan demikian masa inkubasi virus dalam tubuh pasien lebih singkat.

Gejala klinis infeksi virus rabies di manusia dibagi menjadi empat tingkatan, yaitu tingkat tanda timbulnya penyakit (stadium prodromal), tingkat kesadaran (stadium sensoris), tingkat kegelisahan (stadium eksitasi), tingkat kelumpuhan (stadium paralis). Pada kasus di atas, pasien sudah berada dalam tingkat kegelisahan, yaitu menunjukkan gejala khas rabies: airphobia, photophobia, serta hydrophobia. Sebagian besar pasien akan meninggal bila sudah berada pada tingkat kegelisahan. 1,8,9,10

Untuk diagnosis laboratorik, spesimen sebelum meninggal (spesimen ante mortem) dapat diambil dari air liur, hapusan kornea mata, sayatan (biopsi) kulit, folikel rambut, darah dan cairan bilangan otak dan sumsum tulang belakang (serebrospinal). Spesimen pascameninggal (postmortem) biasanya diambil dari otak, saraf tunjang (spinal cord), atau organ lainnya. Berbagai cara memeriksa telah dikembangkan untuk menemukan antigen rabies/virus, antibodi rabies, bangun bentuk dan ciri virus rabies. Menurut WHO, diagnosis untuk menemukan antigen, virus, atau Negri bodies dari rabies dapat dilakukan dengan Polymerase Chain Reaction (PCR). ${ }^{10,11}$ Metode PCR hanya dapat digunakan setelah virus mencapai jaringan otak atau bagian alat tubuh lainnya, dan dalam kenyataan tidak mungkin dilakukan mendiagnosis rabies dalam waktu yang singkat setelah serbuan virus rabies dimulai. ${ }^{12}$

Secara teoretis, hasil memeriksa PCR sebelum meninggal dengan masa inkubasi yang singkat seharusnya menunjukkan hasil yang positif, tetapi kasus di atas hasil memeriksa PCR sebelum meninggal dengan sampel air liur dan air mata menunjukkan hasil yang negatif. Hal tersebut dapat disebabkan jumlah sampel sapuan (swab) air liur dan air mata kurang, sehingga pada saat pemeriksaan diperoleh hasil negatif.

Penatalaksanaan pasien/penderita rabies meliputi pengasingan pasien untuk menghindari rangsangan yang menimbulkan kejang (spasme) otot dan mencegah penularan. Penanganan luka dengan pencucian dengan air mengalir menggunakan sabun/obat pembersih selama 10-15 menit. Kemudian diberikan antiseptik (alkohol, betadine, obat merah, dll), pemberian tetanus toksoid atau tetanus immunoglobulin serta antibiotik, pemberian vaksin anti rabies dan atau serum antirabies. Pengobatan simptomatik dan penunjang (suportif), seperti pemberian pereda (sedatif), penghilang nyeri (analgetik), pencegah kejang (antikonvulsan), pengobatan komplikasi respirasi dan peredaran darah jantung seperti pemasangan ventilator, membersihkan darah serabut (defibrilasi). Setiap kasus gigitan hewan penular rabies harus ditangani dengan cepat dan sesegera mungkin. Di luka berkebahayaan tinggi antara lain luka gigitan ganda (multiple), luka dalam dan lebar, luka di daerah muka, kepala, leher, jari tangan dan kaki, dan jilatan di mukosa. Luka gigitan tidak dibenarkan untuk dijahit, kecuali jahitan yang mempengaruhi luka. Di sekitar luka gigitan yang terpaksa dijahit, perlu disuntik SAR sebanyak mungkin, sisanya disuntikkan ke dalam otot (intramuskuler). Luka berkebahayaan rendah yang tidak berbahaya seperti jilatan di kulit, luka, garukan atau lecet, luka di sekitar tangan, badan, dan kaki, cukup diberikan VAR saja. Untuk sentuhan dengan air liur hewan tersangka rabies, tetapi tidak terdapat luka, baik terjadi sentuhan tidak langsung maupun tidak ada sentuhan tidak perlu diberikan VAR atau SAR. $1,4,13,14$

Vaksin rabies yang lazim saat ini adalah vaksin perbenihan jaringan (tissue culture vaccine), yaitu vaksin yang tankerja (inactivated vaccine) dan ditumbuhkan pada kultur sel seperti human diploid cell vaccine (HDCV). Bahan tersebut dibuat sejak tahun 1964 dengan nama dagang ImovaxR, purified vero cell rabies vaccine (PVRV), dibuat mulai tahun 1985 dengan nama VerorabR, purified chick embryo cell vaccine (PCEC) dengan nama RabipurR yang mulai dipasarkan tahun 1985. Vaksin generasi lama seperti suckling mouse brain vaccine (SMBV), vaksin jaringan saraf (nerve tissue vaccine) tertentu dan duck embryo vaccine (DEV), vaksin non jaringan saraf (non-nerve tissue vaccine) tertentu, tidak digunakan lagi karena dapat menimbulkan penyulit radang otak dan sumsum tulang belakang (ensefalomielitis) pasca vaksinasi dan reaksi renjatan (anafilaksis). PVRV adalah vaksin yang tersedia di Indonesia, merupakan vaksin kering beku, yang setiap satu takaran pengebalan memiliki daya perlindungan lebih besar atau sama dengan 2,5 mL IU. VAR akan mengimbas respons imun secara aktif dengan menghasilkan antibodi penetral (neutralizing antibodies) kira-kira 7-10 hari dan menetap lebih dari dua tahun. Pemberian SAR merupakan pengebalan pasif yang bertujuan untuk segera memberikan antibodi penetral sebelum sistem imun penderita siap untuk menghasilkan antibodi sendiri yang terjadi 7-14 hari setelah VAR diberikan. Ada dua jenis SAR yang digunakan secara luas yaitu human rabies immune globulin (HRIG) dan equine rabies immune globulin (ERIG). SAR yang digunakan di Indonesia adalah serum homolog yang berasal dari serum manusia (HRIG). SAR hanya diberikan pada 
awal pemvaksinasian, jika SAR tidak diberikan pada awalnya masih dapat diberikan sampai hari ke tujuh (7) sejak awal pemberian tersebut. Setelah hari ke tujuh merupakan kontraindikasi SAR, karena telah terjadi respons imun aktif terhadap VAR.4,13

WHO menganjurkan pemberian VAR secara di dalam otot bentuk delta atau depan samping (anterolateral) paha 0,5 $\mathrm{mL}$ pada hari ke 0,3 , 7, 14, 28 (regimen Essen), sedangkan Depkes RI menganjurkan empat kali pemberian dengan dosis 0,5 mL di dalam otot. Baik pemberian VAR maupun SAR dapat menimbulkan pengaruh samping ringan setempat maupun sistemik seperti nyeri, kemerahan kulit (eritema), bengkak bekas tempat suntikan, demam, nyeri kepala, mual, nyeri otot, nyeri sendi. $4,10,13,15$

Pemberian VAR bertujuan agar tubuh penderita mengembangkan sistem kekebalan aktif, baik melalui sistem imun humoral, yaitu antibodi yang akan menetralkan virus yang berada di luar sel maupun dalam sistem kekebalan yang khas, yaitu CTL yang akan menurunkan sel terinfeksi virus rabies. Pengaktifan respons imun yang bersifat cairan dimulai dengan penelanan/fagositosis virus oleh antigen presenting cells (APC). Kemudian setelah diolah, antigen akan diberikan kepada sel limfosit $\mathrm{T}$ helper. Sel T helper selanjutnya membuat berbagai perantara yang akan menggiatkan sel B menjadi sel plasma penghasil antibodi dan cabang lingkungan (sub-set) sel T lainnya menjadi sel berkaitan racun (cytotoxic) yang khas. APC banyak jenisnya, salah satunya adalah sel Langerhans yang keberadaanya di jaringan kulit lebih banyak dibandingkan dengan yang di jaringan otot. Sel Langerhans jika bertemu dengan antigen atas pengaruh TNF $\alpha$ (sitokin proinflamasi) akan aktif, dan melepaskan diri dari susunan jala untuk berpindah ke kulit dan memasuki sistem kelenjar getah bening. Dari sistem kelenjar getah bening aferen kemudian ke kelenjar getah bening untuk berperanserta dalam respons imun dan menyajikan antigen ke sel $\mathrm{T}$ helper. Secara umum, kecepatan dan intensitas respons imun khas dipengaruhi oleh berbagai faktor, di antaranya: jenis vaksin, cara memberikan, dosis dan selang pemberian, umur penerima, status gizi, faktor genetik penerima, faktor hormonal dan penyakit sebelumnya (pre-exiting diseases). ${ }^{16}$

Kegagalan pemberian vaksin kasus di atas dapat disebabkan karena respons imun penderita belum mencukupi, sehingga belum mampu untuk menetralkan antigen virus yang masuk dan membunuh sel yang terinfeksi virus. Oleh karena itu, pemberian vaksin rabies sebaiknya dipantau dengan pemeriksaan kadar antibodi antirabies, angka banding jumlah sel limfosit $\mathrm{CD}^{+}{ }^{+}$dengan limfosit $\mathrm{CD}^{+}$, Interleukin 2 dan Interferon Gamma. Apabila penatalaksanaan untuk pasien rabies tepat dimulai begitu gejala rabies mulai muncul, peramalan jalan penyakit baik. Berbagai telitian dari tahun 1986 sampai 2000 yang melibatkan lebih dari 800 kasus gigitan anjing rabies yang segera mendapat VAR dan SAR menunjukkan angka bertahan hidup 100\%. Namun, bila penatalaksanaannya baru dimulai setelah berbagai gejala rabies muncul, maka peramalan jalan penyakitnya buruk. Kematian karena rabies boleh dikatakan $100 \%$ terjadi bila virus sudah mencapai sistem saraf. ${ }^{4,17}$

\section{SIMPULAN DAN SARAN}

Kasus di atas adalah infeksi virus rabies di anak berusia 5 (lima) tahun, dengan perlukaan di daerah muka, yaitu di kelopak mata bagian bawah. Pada perlukaan di daerah ini, jumlah virus yang masuk dengan jarak yang harus ditempuh virus dari titik pintu masuk ke susunan saraf pusat lebih pendek. Dengan demikian masa inkubasi virus dalam tubuh pasien pun menjadi lebih singkat. Pada penatalaksaan di pasien ini setelah tergigit anjing, ia hanya mendapatkan pengobatan berupa pencucian luka dan VAR dosis I. Padahal rujukan dari buku pedoman Departemen Kesehatan, menyatakan bahwa bila terjadi luka berkebahayaan tinggi antara lain luka gigitan ganda, luka dalam dan lebar, luka di daerah muka, kepala, leher, jari tangan dan kaki, dan jilatan di mukosa perlu disuntik SAR dan VAR. Oleh karena itu sebaiknya setiap petugas kesehatan yang menangani setiap kasus rabies, harus mengacu pada Pedoman yang diterapkan oleh Departemen Kesehatan tersebut.

\section{DAFTAR PUSTAKA}

1. Harijanto PN, Gunawan CA. Rabies. Dalam: Sudoyo AW, Setiyohadi B, Alwi I, Simadibrata M, Setiati S (Eds). Buku Ajar Ilmu Penyakit Dalam. Edisi IV, Jilid III, Jakarta, Pusat Penerbitan Departemen Ilmu Penyakit Dalam FKUI, 2006; 1736-1740.

2. Atmawinata, E. Mengenal Beberapa Penyakit Menular dari Hewan Kepada Manusia. Yarma Widya, Bandung, 2006; 115-121.

3. Dinas Peternakan Propinsi Jawa Barat, 2007. Tentang Rabies. Dinas Peternakan Provinsi Jawa Barat. Diunduh dari: http:// www.disnak.jabarprov.go.id.(accessed July 7, 2010).

4. Gunawan, Carta A. Rabies: Diagnosis dan Penatalaksanaan. CDK 172/vol. 36 no. 6/ September - Oktober 2009.

5. Jejak Wabah Rabies di Bali. Suara Udayana Edisi Maret - April 2010; 3.

6. Evalina, Ita. Karakteristik Tersangka Penderita Rabies di Puskesmas Pancur Batu Kecamatan Pancur Batu Kabupaten Deli Serang Tahun 2007. Skripsi. Fakultas Kesehatan Masyarakat, Universitas Sumatera Utara, Medan 2009; 13-15.

7. Jackson, Alan C. Rabies. Neurol Clin 2008; 26: 717-726.

8. Hanlon CA, Corey L. Rabies virus and other rhabdovirus. In: Kasper DL, Braunwald E, Fauci AS, Hauser SL, Longo DL, Jameson JL (Eds). Harrison's Principles of Internal Medicine. $16^{\text {th }}$ ed, Vol. 1, New York, McGraw-Hill, 2004; 1155-1160.

9. DepKes RI. Petunjuk Perencanaan dan Penatalaksanaan Kasus Gigitan Hewan Tersangka/Rabies di Indonesia. Jakarta, Direktorat Jendral PPM dan PL, 2000; 5-6. 
10. WHO. Rabies: General Aspects \& Laboratory Diagnosis Techniques. 2007; 6-7. Diunduh dari: http://www.whoindia. org (accesed July 7, 2010).

11. McElhinney, L. M, A. R. Fooks, A. D. Radford. Diagnostic Tools for the Detection of Rabies Virus. EJCAP - Vol. 18 - Issue 3 December 2008; 224-231.

12. Takayama, Naohide. Rabies: A Preventable But Incurable Disease. J Infect Chemother 2008; 14: 8-14.

13. Susilawati NM, AA. Raka Sudewi. Profilaksis Rabies. Medicina Volume 40 Nomor 1 Januari 2009; 55-60.

14. Jackson, Alan C, Warrell M J, Rupprecht CE, Hildegund CJ. Ertl, Bernhard Dietzschold, Michael O’Reilly, Richard P. Leach, Zhen F. Fu, William H. Wunner, Thomas P. Bleck, and Henry Wilde. Management of Rabies in Humans. CID 2003:36 (1
January).Diunduh dari: http: //www.cdc.gov/rabies/docs/ management.pdf.

15. WHO. Current Who Guide for Rabies Pre and Post-Exposure Treatments in Human. Diunduh dari: http://www.who.int/ entity/rabies/en/WHO_guide_rabies_pre_post_exp_treat_ humans. (accesed July 7, 2010).

16. Windiyaningsih Cicilia. Respons Imun Pascavaksinasi Antirabies Intradermal Dibandingkan dengan Vaksinasi Antirabies Intramuskular Pada Kasus Gigitan Hewan Penular Rabies di Masyarakat (Disertasi). Fakultas Kesehatan Masyarakat, Universitas Indonesia, 2007; 78.

17. Rabies Treatment. Diunduh dari: http://www.sosindonesia. com/Library/Rabies Treatment.pdf. (accesed July 7, 2010). 